romagnetic exchange interaction has not been found between 80 and $300 \mathrm{~K}$ (Šindeláŕ, 1987). On the other hand the similar compound $[\mathrm{Fe}(\text { saloph })]_{2}$ ter exhibits the expected exchange interaction.

The donor atoms of the saloph in [Fe(saloph) $]_{2}$ ter are expected to be equatorial (square coordination) because of the inflexibility of the saloph ligand, with the bridge donor atoms completing an arrangement similar to that in $\left[\mathrm{Fe}(\text { salen) }]_{2} \mathrm{O}\right.$. Six coordination in $\left[\mathrm{Fe}\right.$ (salen) $\mathrm{Cl}_{2}$ leads to a significant distortion of the salen ligands and, simultaneously, to weaker exchange interaction. The further distortion of the salen ligands in $[\mathrm{Fe}(\text { salen})]_{2}$ ter corresponds to the fact that an exchange interaction has not been found for this compound.

\section{References}

Catti, M. \& Ferrari, G. (1976). Acta Cryst. A32, 163-165.

CleGG, W. (1981). Acta Cryst. A37, 22-28.

Gerloch, M. \& Mabbs, F. E. (1967). J. Chem. Soc. A, pp. 1900-1906.

Gerloch, M., McKenzie, E. D. \& Toivl, A. D. C. (1969). J. Chem. Soc. $A$, pp. 2850-2858.

Hamiton, W. C. (1959). Acta Cryst. 12, 609-610.

Petř́ícek, V., CísaŘová, I. \& Šubrtová, V. (1983). Acta Cryst. C39, 1070-1072.

PeTrर́í́EK, V. \& MALÝ, K. (1990). SDS. A system of computer programs for the solution of structures from X-ray diffraction data. Unpublished.

ShOEMAKer, D. P. (1970). J. Appl. Cryst. 3, 179-180.

ŠINDELÁŕ, Z. (1987). PhD Thesis. Palacký Univ., Czechoslovakia.

Wollmann, R. G. \& Hendrickson, D. N. (1978). Inorg. Chem. 17, 926-930.

Acta Cryst. (1992). C48, 1582-1584

\title{
A Platinum Chloro (Fluoroaryl)phosphine Complex
}

\author{
By William P. Schaefer, David K. Lyon, Jay A. Labinger and John E. BercaW \\ Division of Chemistry and Chemical Engineering* and The Beckman Institute, \\ Mail Code 139-74, California Institute of Technology, Pasadena, California 91125, USA
}

(Received 27 September 1991; accepted 21 January 1992)

\begin{abstract}
Dichlorobis[tris(pentafluorophenyl)phosphine]platinum(II), $\left[\mathrm{PtCl}_{2}\left\{\mathrm{P}\left(\mathrm{C}_{6} \mathrm{~F}_{5}\right)_{3}\right\}_{2}\right], \quad M_{r}=$ 1330.29, triclinic, $P \overline{1}, a=9.536(4), b=11.221(2), c$ $=11.613(1) \AA, \quad \alpha=62.55(1), \quad \beta=65.81(2), \quad \gamma=$ $73.05(2)^{\circ}, \quad V=997.8(4) \AA^{3}, \quad Z=1, \quad D_{x}=$ $2.21 \mathrm{~g} \mathrm{~cm}^{-3}, \quad \lambda($ Mo $K \alpha)=0.71073 \AA, \quad \mu=$ $39.27 \mathrm{~cm}^{-1}, F(000)=628$, room temperature, $R=$ 0.034 for 3497 reflections with $F_{o}^{2}>0$. The molecule is centrosymmetric, with $\mathrm{Pt}-\mathrm{Cl}$ distance 2.304 (2) and $\mathrm{Pt}-\mathrm{P} 2.280(1) \AA$, and $\mathrm{P}-\mathrm{Pt}-\mathrm{Cl}$ angle $94.8(1)^{\circ}$. The $\mathrm{C}-\mathrm{P}$ distances average 1.824 (4) $\AA$, slightly longer than normal, and the pentafluorophenyl groups all have small $\left[116.3(3)^{\circ}\right]$ angles at the $\mathrm{c}$ atom bonded to $\mathrm{P}$.
\end{abstract}

Introduction. Platinum(II) halide complexes of the sterically demanding ligand tris(pentafluorophenyl)phosphine [cone angles $=184^{\circ}$ (Tolman, 1977)] have received cursory examination in the literature owing to the presence of rotational isomers in solution at reduced temperature (Kemmitt, Nichols \& Peacock, 1967; Docherty, Rycroft, Sharp \& Webb, 1979). An X-ray crystal-structure analysis of trans$\left[\mathrm{PtI}_{2}\left\{\mathrm{P}\left(\mathrm{C}_{6} \mathrm{~F}_{5}\right)_{3}\right\}_{2}\right]$ has been reported demonstrating that the complex does not contain substantial distor-

* Contribution No. 8515 .

0108-2701/92/091582-03\$06.00 tion of the metal coordination sphere despite the steric demands of the bulky phosphine and iodide ligands (Hunter, Muir \& Sharp, 1986). Our interest in the title compound arose as a result of our continuing studies into electrophilic alkane activation and functionalization by platinum chloride solutions (Labinger, Herring \& Bercaw, 1990a,b; Herring, Henling, Labinger \& Bercaw, 1991) and recent reports noting the novel reactivity demonstrated by organometallic complexes containing fluoroalkylphosphines (Ernst \& Roddick, 1989, 1990a,b; Koola \& Roddick, 1991). The previously unreported synthesis of trans- $\left.\left[\mathrm{PtCl}_{2}\left\{\mathrm{P}_{\left(\mathrm{C}_{6}\right.} \mathrm{F}_{5}\right)\right\}_{2}\right]$ was performed analogously to routes described in the literature for triphenylphosphine complexes of $\left[\mathrm{Pt} X_{2}\right]$ (Haake \& Mastin, 1971; Gillard \& Pilbrow, 1974) and gave the complex in good yield $(73 \%)$.

Experimental. Synthesis of trans $-\left[\mathrm{PtCl}_{2}\left\{\mathrm{P}\left(\mathrm{C}_{6} \mathrm{~F}_{5}\right)_{3}\right\}_{2}\right]$ : $\mathrm{PtCl}_{2}(266.0 \mathrm{mg}, 1.0 \mathrm{mmol})$ and $\mathrm{P}\left(\mathrm{C}_{6} \mathrm{~F}_{5}\right)_{3}(1067.2 \mathrm{mg}$, $2.0 \mathrm{mmol}$ ) were placed in a $100 \mathrm{~mL}$ round-bottom flask equipped with a condenser. The apparatus was connected to a vacuum line with a $180^{\circ}$ needle-valve and evacuated for $c a 3 \mathrm{~h}$. Toluene $(50 \mathrm{~mL})$ was vacuum-transferred onto the solids and the slurry was refluxed for $48 \mathrm{~h}$ under an argon atmosphere. The toluene was then removed under vacuum and

C 1992 International Union of Crystallography 
Table 1. Final atomic coordinates $\left(\times 10^{4}\right)$ and equivalent isotropic displacement parameters $\left(\AA^{2} \times 10^{4}\right)$

$$
U_{\mathrm{eq}}=(1 / 3) \sum_{i} \sum_{j} U_{i j} a_{i}{ }^{*} a_{j}{ }^{*} \mathbf{a}_{i} \cdot \mathbf{a}_{j} .
$$

$\begin{array}{lrccc} & x & y & z & U_{\text {eq }} \\ \text { Pt } & 0 & 0 & 0 & 273(1) \\ \text { C1 } & 1968(2) & 1318(2) & -994(1) & 474(3) \\ \text { P } & -307(2) & 471(1) & -2020(1) & 304(3) \\ \text { C1 } & -2132(6) & 1378(5) & -2325(5) & 344(11) \\ \text { C2 } & -3316(6) & 1909(5) & -1435(6) & 393(12) \\ \text { C3 } & -4646(6) & 2692(5) & -1756(6) & 446(14) \\ \text { C4 } & -4764(6) & 2996(5) & -3001(6) & 437(14) \\ \text { C5 } & -3597(7) & 2488(6) & -3911(6) & 458(13) \\ \text { C6 } & -2313(6) & 1710(5) & -3579(6) & 392(12) \\ \text { F2 } & -3230(4) & 1731(4) & -260(4) & 603(9) \\ \text { F3 } & -5753(4) & 3192(4) & -876(4) & 645(10) \\ \text { F4 } & -5991(4) & 3793(4) & -3344(4) & 662(10) \\ \text { F5 } & -3720(4) & 2788(4) & -5127(4) & 691(10) \\ \text { F6 } & -1177(4) & 1249(4) & -4499(3) & 519(8) \\ \text { C11 } & 1033(6) & 1573(5) & -3540(5) & 360(12) \\ \text { C12 } & 857(6) & 2892(5) & -3659(6) & 410(13) \\ \text { C13 } & 1805(7) & 3820(6) & -4715(7) & 521(16) \\ \text { C14 } & 3009(8) & 3451(7) & -5692(7) & 578(17) \\ \text { C15 } & 3247(7) & 2151(7) & -5616(6) & 543(17) \\ \text { C16 } & 2259(7) & 1229(6) & -4555(6) & 437(13) \\ \text { F12 } & -306(4) & 3299(3) & -2729(4) & 526(9) \\ \text { F13 } & 1576(5) & 5092(3) & -4783(4) & 732(12) \\ \text { F14 } & 3939(5) & 4344(4) & -6727(4) & 887(14) \\ \text { F15 } & 4411(5) & 1772(5) & -6567(4) & 814(13) \\ \text { F16 } & 2505(4) & 0(4) & -4575(4) & 591(9) \\ \text { C21 } & -39(6) & -1160(5) & -2134(5) & 370(12) \\ \text { C22 } & 1327(7) & -1992(6) & -1954(6) & 448(13) \\ \text { C23 } & 1582(8) & -3329(6) & -1771(7) & 586(18) \\ \text { C24 } & 456(9) & -3861(6) & -1777(7) & 635(20) \\ \text { C25 } & -897(9) & -3091(6) & -1937(7) & 574(17) \\ \text { C26 } & -1126(7) & -1743(5) & -2114(6) & 440(14) \\ \text { F22 } & 2432(4) & -1491(4) & -1934(4) & 586(9) \\ \text { F23 } & 2906(5) & -4083(4) & -1593(5) & 924(14) \\ \text { F24 } & 679(6) & -5164(4) & -1593(5) & 938(15) \\ \text { F25 } & -2009(6) & -3619(4) & -1910(5) & 867(13) \\ \text { F26 } & -2527(4) & -1058(3) & -2213(4) & 638(10) \\ & & & & \end{array}$

Table 2. Selected distances $(\AA)$ and angles $\left({ }^{\circ}\right)$

$\begin{array}{ll}\mathrm{Pt}-\mathrm{P} & 2.280(1) \\ \mathrm{Pt}-\mathrm{Cl} & 2.304(2) \\ \mathrm{P}-\mathrm{Cl} & 1.824(6) \\ \mathrm{P}-\mathrm{Cl} 1 & 1.827(6) \\ \mathrm{P}-\mathrm{C} 21 & 1.832(6)\end{array}$

$\begin{array}{lr}\mathrm{P}-\mathrm{Pt}-\mathrm{Cl} & 94.8(1) \\ \mathrm{Pt}-\mathrm{P}-\mathrm{Cl} & 119.6(2) \\ \mathrm{Pt}-\mathrm{P}-\mathrm{C} 11 & 114.5(2) \\ \mathrm{Pt}-\mathrm{P}-\mathrm{C} 21 & 106.4(2) \\ \mathrm{C} 1-\mathrm{P}-\mathrm{C} 11 & 99.4(3) \\ \mathrm{Cl}-\mathrm{P} 1-\mathrm{C} 21 & 106.7(3) \\ \mathrm{C} 11-\mathrm{P}-\mathrm{C} 21 & 109.8(3)\end{array}$

the residue was extracted with portions of $\mathrm{CH}_{2} \mathrm{Cl}_{2}(4$ $\times 25 \mathrm{~mL}$ ) until the supernatant was colorless. The solution was filtered through Whatman \#1 paper to remove any unreacted brown $\mathrm{PtCl}_{2}$. The solvent was removed under vacuum leaving a yellow solid which was recrystallized from $\mathrm{CH}_{2} \mathrm{Cl}_{2}$ /heptane and dried under vacuum for $4 \mathrm{~h}$ to yield $970.0 \mathrm{mg}(0.73 \mathrm{mmol}$, $73 \%$ yield) of a microcrystalline solid. Elemental analysis: $\mathrm{C}$ calculated 32.5 ; $\mathrm{C}$ found $32.34 \% .{ }^{31} \mathrm{P}$ NMR $\delta-26.7$ (triplet, ${ }^{2} J_{\mathrm{Pt}-\mathrm{P}}=3140 \mathrm{~Hz}$ ). ${ }^{19} \mathrm{~F}$ NMR $\delta-127.0\left(b r, 2 \mathrm{~F}, o\right.$-fluoro), -144.4 (triplet, ${ }^{2} J_{\mathrm{F}-\mathrm{F}}=$ $18.3 \mathrm{~Hz}, \quad 1 \mathrm{~F}, \quad p$-fluoro), -160.1 (pseudotriplet, ${ }^{2} J_{\mathrm{F}-\mathrm{F}(\mathrm{av} .)}=20 \pm 2 \mathrm{~Hz}, 2 \mathrm{~F}, m$-fluoro).

Structure determination: a parallelepiped crystal, $0.11 \times 0.15 \times 0.23 \mathrm{~mm}$, was used for data collection on a CAD-4 diffractometer with $\omega-2 \theta$ scans; 25 reflections with $28<2 \theta<31^{\circ}$ were used to determine the cell dimensions. An empirical absorption correction based on $\psi$ scans was applied, with relative transmission factors from 0.819 to 1.119 . $(\sin \theta / \lambda)_{\max }$
$=0.59 \AA^{-1} ; h$ from -11 to $11, k$ from -13 to $13, l$ from -13 to 13 . Three standard reflections $(013$, $11 \overline{2}, \overline{2} 11)$ showed no variations greater than those predicted by counting statistics. 7287 reflections were measured, of which 3504 were independent. Goodness of fit for merging was $1.07 ; R_{\text {merge }}=0.018$ for 3470 reflections with exactly two observations. All reflections were used in solution and refinement of the structure. The structure was solved by placing the $\mathrm{Pt}$ atom at the origin and calculating a Fourier map, with all atoms found in that and a subsequent map. $F_{o}{ }^{2}$ values were used in refinement, which minimized $\sum w\left(F_{o}^{2}-F_{c}^{2}\right)^{2}$; positional and anisotropic displacement parameters of all atoms $(x, y, z$ of $\mathrm{Pt}$ fixed at $0,0,0)$, a scale factor and a secondary-extinction factor (232 parameters) were refined in one full matrix; $R=0.032$ for 3442 reflections with $F_{o}^{2}>$ $3 \sigma\left(F_{o}^{2}\right), w R\left(\right.$ on $\left.F^{2}\right)=0.006 ; S=2.10 ; w=1 / \sigma^{2}\left(F_{o}^{2}\right)$, variances of the reflections $\left[\sigma^{2}\left(F_{o}^{2}\right)\right]$ derived from counting statistics plus an additional term, $(0.014 I)^{2}$, variances of the merged data by propagation of error plus another additional term, $(0.014 I)^{2}$; maximum $(\Delta / \sigma)$ in the final least-squares cycle was 0.03 ; maximum $\Delta \rho$ in the final difference map was 2.1 and -2.4 e $\AA^{-3}$ near $\mathrm{Pt}$, and 0.63 and -0.93 e $\AA^{-3}$ elsewhere. The secondary-extinction coefficient (Larson, 1967) was $0.76(9) \times 10^{-6}$. Scattering factors and values for $f^{\prime}$ were taken from Cromer \& Waber (1974) and Cromer (1974). Programs used were those of the CRYM crystallographic computing system (Duchamp, 1964) and ORTEP (Johnson, 1976). Final parameters are given in Table 1 , with selected distances and angles in Table 2.*

Discussion. This centrosymmetric Pt compound exhibits square planar coordination: the $\mathrm{Pt}-\mathrm{Cl}$ and $\mathrm{Pt}-\mathrm{P}$ bonds are nearly the same length and the $\mathrm{Cl}-\mathrm{Pt}-\mathrm{P}$ angle is $94.8(5)^{\circ}$. The $\mathrm{Pt}-\mathrm{Cl}$ bond, 2.304 (2) $\AA$, is slightly shorter than found on average, but is in the normal range; the compilation of Orpen, Brammer, Allen, Kennard, Watson \& Taylor (1989) gives 2.323 (38) $\AA$ for 293 examples of fourcoordinate $\mathrm{Pt}$. The $\mathrm{Pt}-\mathrm{P}$ distance is similarly short, 2.280 (1) compared to 2.298 (32) $\AA$ from the same compilation. The $\mathrm{Pt}-\mathrm{P}$ bond is somewhat shorter than that reported for trans- $\left[\mathrm{PtI}_{2}\left\{\mathrm{P}\left(\mathrm{C}_{6} \mathrm{~F}_{5}\right)_{3}\right\}_{2}\right]$, 2.292 (6) $\AA$ (Hunter et al., 1986). However, the $\mathrm{P}-\mathrm{C}$ bond (pentafluorophenyl) distances at $1.828(4) \AA$ are comparable to those reported by Hunter et al. (1986) for trans- $\left[\mathrm{PtI}_{2}\left\{\mathrm{P}\left(\mathrm{C}_{6} \mathrm{~F}_{5}\right)_{3}\right\}_{2}\right] \quad[1.831(24) \AA]$.

\footnotetext{
* Lists of anisotropic displacement parameters, complete distances and angles, and observed and calculated structure factors have been deposited with the British Library Document Supply Centre as Supplementary Publication No. SUP 55071 (20 pp.). Copies may be obtained through The Technical Editor, International Union of Crystallography, 5 Abbey Square, Chester CHI 2HU, England. [CIF reference: HH0588]
} 
$\mathrm{P}-\mathrm{C}$ distances in both compounds are slightly longer than the 1.793 (11) $\AA$ compiled for aromatic C to four-coordinate $\mathrm{P}$ (Allen, Kennard, Watson, Brammer, Orpen \& Taylor, 1987). One could expect that the fluoro substituents on the phenyl rings would cause such a lengthening; their influence is also seen in the closing down of the interior angle at the P-bonded $\mathrm{C}$ atom to $116.3(3)^{\circ}$, with a concomitant opening of the two interior angles at the ortho $\mathrm{C}$ atoms to $122.5(5)^{\circ}$. The other interior angles in the phenyl groups average $119.7(6)^{\circ}$, as expected. The $\mathrm{C}-\mathrm{C}$ distances in the rings come in two sets. Those next to the $\mathrm{P}$-bonded $\mathrm{C}$ atom average 1.387 (12) $\AA$, while the remainder are 1.375 (12) $\AA$; this latter distance compares well with that of 1.372 (11) $\AA$ given by Allen et al. (1987). The C-F distances are also normal at 1.338 (9) $\AA$, compared to 1.340 (9) $\AA$ [167 examples (Allen et al., 1987)].

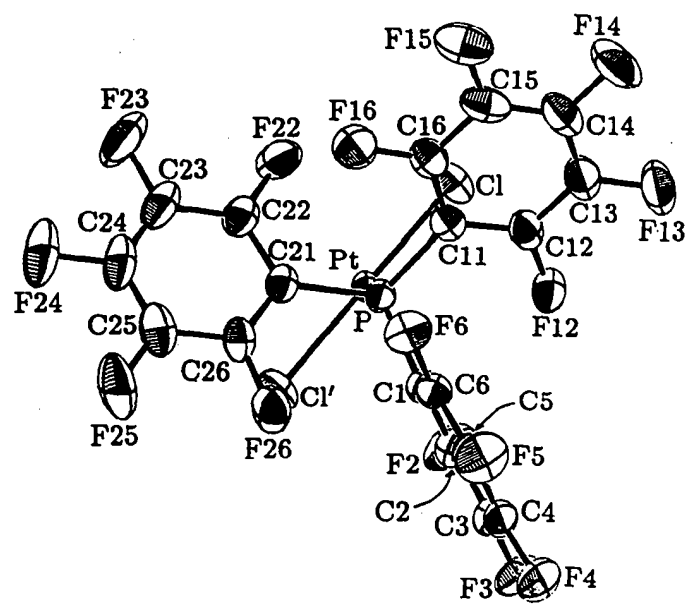

Fig. 1. An ORTEPII (Johnson, 1976) drawing of part of the molecule projected perpendicular to the $\mathrm{C} 1, \mathrm{C} 11, \mathrm{C} 21$ plane with $50 \%$ probability ellipsoids showing the numbering system. The two $\mathrm{Cl}$ atoms are shown, but only one phosphine ligand is pictured.

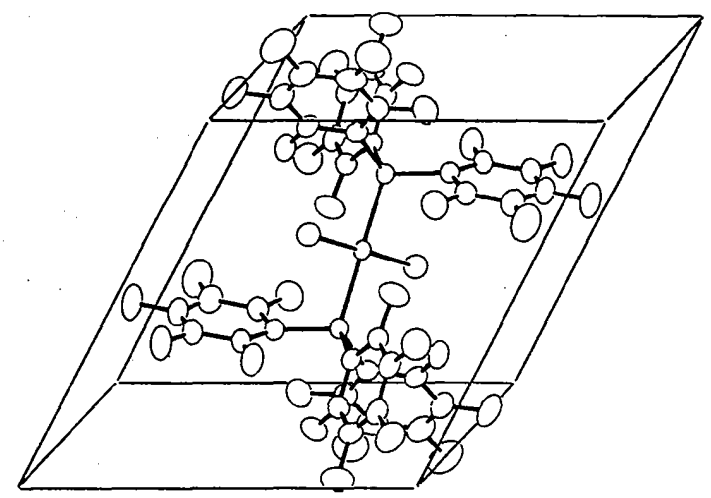

Fig. 2. An ORTEPII (Johnson, 1976) drawing of the molecule, translated to the center of the triclinic cell that is outlined, so that the Pt coordinates are $\frac{1}{2}, \frac{1}{2}, \frac{1}{2}$. Atoms are shown as $50 \%$ probability ellipsoids.
Fig. 1 shows a view of half the molecule and reveals another effect of the $F$ atoms. The pentafluorophenyl groups are not arranged symmetrically about the $\mathrm{Pt}-\mathrm{P}$ axis, but twist (one to being parallel to that axis) to minimize interatomic contacts. The result is an efficient packing, with five $F \cdots \cdot$ F contacts less than $2.9 \AA$, the shortest being $2.80 \AA$; the van der Waals radius of $F$ is $1.35 \AA$ (Pauling, 1960). The related trans-[PtI $\left.\left\{\mathrm{P}_{2}\left(\mathrm{C}_{6} \mathrm{~F}_{5}\right)_{3}\right\}_{2}\right]$ shows no similar efficient packing (Hunter et al., 1986). All other contacts are at greater than van der Waals distances. Fig. 2 shows the whole molecule in a view from which the packing can be inferred.

This work was supported by the Office of Naval Research (Grant No. N00014-89-J-3198), which is gratefully acknowledged.

\section{References}

Allen, F. H., Kennard, O., Watson, D. G., Brammer, L., OrPen, A. G. \& TAYLOR, R. (1987). J. Chem. Soc. Perkin Trans. pp. S1-S19.

CROMER, D. T. (1974). International Tables for X-ray Crystallography, Vol. IV, pp. 149-151. Birmingham: Kynoch Press. (Present distributor Kluwer Academic Publishers, Dordrecht.)

CROMER, D. T. \& WABER, J. T. (1974). International Tables for $X$-ray Crystallography, Vol. IV, pp. 99-101. Birmingham: Kynoch Press. (Present distributor Kluwer Academic Publishers, Dordrecht.)

Docherty, J. B., Rycroft, D. S., Sharp, D. W. A. \& WebB, G. A. (1979). J. Chem. Soc. Chem. Commun. pp. 336-337.

DUCHAMP, D. J. (1964). CRYM crystallographic computing system. Am. Crystallogr. Assoc. Meet., Bozeman, Montana. Paper B-14, p. 29.

ERnst, M. F. \& Roddick, D. M. (1989). Inorg. Chem. 28, 1624-1627.

ERnst, M. F. \& Roddick, D. M. (1990a). Inorg. Chem. 29, 3627-3630.

ERNST, M. F. \& RodDICK, D. M. (1990b). Organometallics, 9, 1586-1594.

Gillard, R. D. \& Pilbrow, M. F. (1974). J. Chem. Soc. Dalton Trans. pp. 2320-2325.

HAAKe, P. \& Mastin, S. H. (1971). J. Am. Chem. Soc. 93, 6823-6828.

Herring, A. M., Henling, L. M., Labinger, J. A. \& BerCaw, J. E. (1991). Inorg. Chem. 30, 851-853.

Hunter, W. N., MUIR, K. W. \& Sharp, D. W. A. (1986). Acta Cryst. C42, 1743-1745.

JoHNSON, C. K. (1976). ORTEPII. Report ORNL-3794, third revision. Oak Ridge National Laboratory, Tennessee, USA.

Kemmitt, R. D. W., Nichols, D. I. \& Peacock, R. D. (1967). J. Chem. Soc. Chem. Commun. pp. 599-601.

Koola, J. \& Roddick, D. M. (1991). J. Am. Chem. Soc. 113, 1450-1452.

Labinger, J. A., Herring, A. M. \& Bercaw, J. E. (1990a). J. Am. Chem. Soc. 112, 5628-5630.

Labinger, J. A., Herring, A. M. \& Bercaw, J. E. (1990b). Am. Chem. Soc. Symp. Ser. In the press.

Larson, A. C. (1967). Acta Cryst. 23, 664-665.

Orpen, A. G., Brammer, L., Allen, F. H., Kennard, O., Watson, D. G. \& TaYlor, R. (1989). J. Chem. Soc. Dalton Trans. pp. S1-S38.

Pauling, L. (1960). The Nature of the Chemical Bond, p. 260. Cornell Univ. Press.

Tolman, C. (1977). Chem. Rev. 77, 313-348. 